\title{
EVALUASI PROGRAM PENDIDIKAN DAN PELATIHAN KEPEMIMPINAN TINGKAT IV DALAM KEBIJAKAN PENGEMBANGAN KOMPETENSI ASN DI PEMERINTAH KABUPATEN LAHAT
}

\author{
Dian Novita Fajar Sari ${ }^{11}$ \\ 1)Sekolah Tinggi Ilmu Administrasi (STIA) Satya Negara Palembang \\ Jl. Sukatani 3, 8 Ilir Kecamatan Ilir Timur II, Kota Palembang, \\ Sumatera Selatan 30961 \\ e-mail : novipusri@gmail.com
}

\begin{abstract}
Abstrak
Penelitian ini bertujuan untuk mengevaluasi Program Pendidikan Dan Pelatihan Kepemimpinan (Diklatpim) Tingkat IV dengan menggunakan model evaluasi COPP yang dikembangkan oleh Stufflebeam. Model evaluasi CIPP diharapkan dapat menghasilkan evaluasi yang kompleks dari program Diklatpim tingkat IV tahun 2016 di Pemerintah Kabupaten Lahat. Didasari dengan penggunaan model evaluasi tersebut, maka metode penelitian kualitatif dengan pendekatan studi kasus dipilih oleh peneliti. Pengumpulan data dilakukan dengan wawancara dan studi dokumentasi terkait dengan penyelenggaraan Diklatpim tingkat IV tahun 2016. Adapun informan pada penelitian ini berjumlah 15 orang yang berasal dari Badan Kepegawaian dan Pengembangan Sumber Daya Manusia (BKPSDM) Kabupaten Lahat Provinsi Sumatera Selatan, Balai Pengembangan Sumber Daya Manusia Daerah (BPSDMD) Provinsi Sumatera selatan dan peserta Diklatpim tingkat IV tahun 2016 di pemerintah Kabupaten Lahat. Apabila dilihat dari aspek process dan product yang dilaksanakan, hasil penelitian menunjukan bahwa program Diklatpim tingkat IV Tahun 2016 di Kabupaten Lahat telah sesuai dengan peraturan yang berlaku dan dianggap berhasil. Namun berdasarkan aspek context dan input, terdapat beberapa hal yang tidak sesuai dengan maksud dan tujuan dari program Diklatpim tingkat IV di pemerintah Kabupaten Lahat.
\end{abstract}

Kata kunci: evaluasi; model CIPP; Diklatpim tingkat IV; pengembangan kompetensi

\begin{abstract}
This study aims to evaluate the Level IV Leadership Education and Training Program (Diklatpim) using the COPP evaluation model developed by Stufflebeam. The CIPP evaluation model is expected to produce a complex evaluation of the 2016 Level IV Diklatpim program in the Lahat District Government. Based on the use of the evaluation model, the qualitative research method with a case study approach was chosen by the researcher. Data collection was carried out by interviewing and studying documentation related to the implementation of Level IV Diklatpim in 2016. The informants in this study amounted to 15 people who came from the Agency for Personnel and Human Resources Development (BKPSDM) Lahat Regency, South Sumatra Province, Regional Human Resources Development Center. (BPSDMD) South Sumatra Province and participants of Level IV Training and Education in 2016 in the Lahat Regency government. When viewed from the aspects of the process and product implemented, the results of the study show that the 2016 Level IV Education and Training program in Lahat Regency has been in accordance with applicable regulations and is considered successful. However, based on the context and input aspects, there are several things that are not in accordance with the aims and objectives of the Level IV Diklatpim program in the Lahat Regency government.
\end{abstract}


Keywords: evaluation; CIPP models; Level IV training and education; competency development

\section{LATAR BELAKANG}

Perubahan-perubahan yang cepat di tingkat global dan nasional serta tuntutan dari masyarakat akan pelayanan publik yang lebih baik merupakan faktor pendorong yang kuat bagi organisasi publik untuk melakukan perubahan demi menyelesaikan kompleksitas masalah bagi para pelaksana organisasi publik (Effendi, 2010). Sumber daya manusia yang sesuai dengan tuntutan kebutuhan organisasi menjadi syarat mutlak dalam menciptakan organisasi yang berkinerja tinggi (Mukhopadhyay, Sil, \& Banerjea, 2011). Hal ini sejalan dengan tuntutan dari Undang- Undang Nomor 5 Tahun 2014 tentang Aparatur Sipil Negara (ASN) atau sering disebut dalam kalangan birokrat dengan UU ASN, bahwa untuk mewujudkan ASN yang berkualitas dapat dibangun dengan mengoptimalkan kompetensi yang dimiliki oleh setiap pegawai.

Beberapa penelitian terdahulu mengungkapkan bahwa untuk mengoptimalkan kompetensi para ASN, Diklat merupakan nilai penting untuk menambah dan memfasilitasi para pegawainya dalam mencapai kecakapan untuk memenuhi tuntutan pekerjaan dan tujuan organisasi (Rajendran \& Udayasuriyan, 2015). Selaras dengan hal tersebut pada pasal 70 UndangUndang Nomor 5 tahun 2014 tentang Aparatur Sipil Negara, pengembangan kompetensi dapat dilakukan melalui kegiatan pendidikan dan pelatihan (Diklat) yang berkelanjutan bagi ASN. Sedangkan dari data yang peneliti dapatkan terlihat masih banyak pejabat struktural eselon IV dilingkungan pemerintah Kabupaten Lahat yang belum mengikuti Diklatpim tingkat IV (45,6 \% dari pejabat yang menduduki posisi Eselon IV). Angka tersebut menunjukkan Diklatpim tingkat IV masih sangat dibutuhkan dalam menunjang kompetensi pejabat struktural eselon IV dilingkungan pemerintah Kabupaten Lahat.

Meningkatnya kebutuhan program Diklatpim tingkat IV menjadikan pengeluaran pada sektor pelatihan dan pengembangan dalam pemerintah Kabupaten Lahat juga meningkat. Dengan besarnya pengeluaran dan pentingnya bagi syarat wajib ASN yang akan atau telah menduduki jabatan 
struktural eselon IV, sudah sewajarnya bahwa kegiatan Diklatpim tingkat IV ini memberikan dampak yang signifikan terhadap pemerintah Kabupaten Lahat. Karena pada dasarnya tidak lebih dari $10 \%$ pengeluaran pelatihan dan pengembangan yang dilakukan benar-benar menghasilkan transfer ke pekerjaan (Baldwin dan Ford dalam (Topno, 2012). Hal ini terlihat dalam realita di lapangan, masih banyak aparatur pemerintah yang berpandangan bahwa keikutsertaan dalam pendidikan dan pelatihan hanya dilihat sebagai kegiatan penyerapan anggaran dan sebuah batu loncatan untuk menduduki jabatan lebih tinggi dengan mengesampingkan penguasaan pengetahuan dan keahlian yang dicapai dalam Diklat (Yustiono, 2009).

Manajemen sumber daya manusia merupakan salah satu instrumen penting bagi organisasi dalam mencapai tujuannya dengan melihat sinkronisasi antara pengelolan SDM dengan pencapaian visi organisasi (Dessler, 2015). Bagi sektor pemerintah, fungsi manajemen SDM adalah untuk mengoptimalisasikan potensi ASN dalam hal secara efektif dan efisien (Thoha, 2014). Dengan pekerjaan yang khas pada jabatan sektor pemerintah, dibutuhkannya kompetensi khusus agar pekerjaan tersebut dapat terselesaikan.

Mengembangkan kompetensi ASN akan meningkatkan kemampuan organisasi secara substansial terhadap tujuan organisasi (Mukhopadhyay et al., 2011). SDM sektor publik di Indonesia dituntut untuk lebih dinamis dalam merespon perubahan lingkungan dan pergeseran manajemen SDM di Indonesia. Semakin baiknya kualitas SDM yang bertugas melayani atau memenuhi permintaan pelanggan (baik internal/eksternal perusahaan), maka semakin baik pula kompetensi SDM tersebut dalam hal teknologi dan elemen/bidang lainnya (Drejer, 2001). Oleh karena itu, menjadikan ASN yang ideal dan kompetitif di era globalisasi merupakan tuntutan publik dan target yang harus dicapai.

Permasalahan kompetensi yang dihadapi pemerintah daerah di indonesia saat ini terdapat pada setiap tingkatan. Hal itu dikarenakan masih lemahnya kemampuan sumber daya aparatur dari level manajer hingga level non manajerial (Abdussamad, 2017). Perlu adanya tatanan pengembangan kompetensi secara jelas, terukur dan konkret dalam 
menentukan arah perencanaan demi tercapainya kompetensi pegawai yang optimal (Wu, 2013). Kompetensi optimal merupakan kompetensi yang dibangun berdasarkan pengetahuan maupun pengalaman. Artinya kompetensi optimal tidak hanya didasari oleh pendidikan formal (pendidikan dasar dan pendidikan tinggi) melainkan juga didasari pendidikan non-formal (berupa pelatihan dan pengembangan pegawai).

Setiap elemen umum dari kompetensi dapat dikembangkan, namun kompetensi tidak akan berkembang selama elemen dari manusia nya tidak mau diubah. Substansi penting pengembangan SDM dalam era good governance adalah perubahan paradigma, sikap, dan perilaku para aparatur pemerintah (sulistiyani et.al 2011 : 33). Dalam ranah pemerintahan, Diklat termasuk dalam salah satu program untuk mengembangkan kompetensi yang dimiliki oleh ASN. Sebagaimana yang disampaikan oleh (Hasibuan, 2014) istilah pendidikan dan pelatihan dalam suatu instansi atau organisasi biasanya disatukan menjadi Diklat, namun secara teoritik mempunyai arti yang berbeda. Pendidikan adalah suatu perluasan individu sehingga dia dapat dipersiapkan untuk menilai berbagai situasi dan memilih respon yang paling tepat berdasarkan kebutuhan organisasi (Simamora, 2016:274). Sedangkan pelatihan menurut M. J. Julius dalam (Suwanto, 2011:30) adalah kegiatan yang secara khusus berkaitan dengan pengadaan, pengembangan, pemanfaatan, dan pemeliharaan agar sumber daya manusia dapat melakukan sesuatu yang efisien. Pada Peraturan Pemerintah Nomor 17 Tahun 2017 diatur mengenai Diklat bagi ASN ada 2 (dua) jenis yaitu, Diklat Prajabatan yang merupakan syarat pengangkatan CPNS menjadi PNS dan Diklat dalam jabatan untuk mengembangkan pengetahuan, keterampilan, dan sikap agar dapat melaksanakaan tugas- tugas dengan sebaik-baiknya. Perubahan yang cukup signifikan sebagai upaya penyempurnaan pedoman penyelenggaraan Pendidikan dan Pelatihan Kepemimpinan Tingkat IV Pola baru mencakup pada materi pembelajaran yang dirancang untuk meningkatkan kemampuan kepemimpinan (leadership) birokrasi di sektor publik dalam memimpin proses perubahan diinstansinya (Dwiyanto, 2013). Kemampuan kepemimpinan sangat dibutuhkan dalam sebuah organisasi, karena hal itu dapat menghasilkanperubahan yang berguna bagi organisasi yang dipimpinnya (Kotter, 1990). 
Evaluasi dilaksanakan untuk melihat bagaimana suatu program mencapai efektifitasnya, baik dari fase perencanaan, pelaksanaan, dan hasil yang dicapai (Saks \& Belcourt, 2006). Arikunto mengutip apa yang dikatakan Suchman bahwa evaluasi sebagai sebuah proses menentukan hasil yang telah dicapai beberapa kegiatan yang direncanakan untuk mendukung tercapainya tujuan (Arikunto \& Jabar, 2008). Menurut Arikunto dan Abdul Jabar (2008:22) ada empat kemungkinan kebijakan yang dapat dilakukan berdasarkan hasil evaluasi pelaksanaan program yaitu: 1) Menghentikan program, 2) Merevisi program, 3) Melanjutkan program, 4) Menyebarkan program.

Adanya evaluasi bertujuan mengetahui apakah pengembangan dan pelatihan sebagai investasi dalam produktivitas karyawan dilakukan secara efektif atau tidak (Topno, 2012). Evaluasi adalah bagian yang penting dalam pengembangan kompetensi Aparatur Sipil negara, hasil dari evaluasi itu sendiri untuk melihat sebagaimana efektifnya suatu Diklat ang direncanakan dan dilaksanakan oleh sebuah lembaga negara terhadap tujuan organisasi itu sendiri.

\section{Konsep evaluasi model CIPP (Context, Input, Process and Product)}

Model CIPP merupakan sebuah panduan bagi para pembuat kebijakan untuk mengumpulkan data evaluasi dengan sistematis. Menurut (Mirzazadeh, Gandomkar, \& Mortaz, 2016) dalam penelitiannya, ada beberapa poin penting yang ditemukan dalam model CIPP, yaitu : (1) Model CIPP membahas semua langkah dari program pendidikan, bahkan ketika program tersebut masih dikembangkan; (2) Evaluasi konteks sangat penting dalam meyakinkan pembuat kebijakan pada awal pembenaran program.Evaluasi input memiliki salah satu manfaat yaitu mampu menyelamatkan sumber daya berharga yang mungkin saja hilang bila dilakukan dengan cara evaluasi di akhir program (output nya saja); (3) Model CIPP memberikan informasi yang berkelanjutan kepada para pembuat keputusan untuk memastikan bahwa program yang diterapkan berada di jalur yang tepat; dan (4) Model evaluasi CIPP mungkin gagal menjawab beberapa pertanyaan evaluasi yang penting tetapi tidak terencana dan hal tersebut dapat memunculkan beban evaluasi. 
Untuk memudahkan pelaksanaan evaluasi, maka dengan mengadopsi model evaluasi CIPP (Stufflebeam \& Zhang, 2017) disusun indikator-indikator dalam konteks, input, proses dan Produk yang digunakan dalam melaksanakan evaluasi ini, yaitu: (a) Evaluasi Konteks dengan indikator yang ada dalam menilai landasan dan tujuan program Diklatpim Tingkat IV seperti ; Undang- Undang, Peraturan Pemerintah tentang keputusan Diklatpim Tingkat IV, para peserta dilihat dari jumlah dan kualifikasi peserta Diklatpim Tingkat IV; (b) Evaluasi Input dengan indikator: keadaan Widyaiswara (rasio jumlah Widyaiswara dengan kebutuhan Diklat, kualifikasi akademik Widyaiswara, kesesuaian kompetensi dengan bidang yang diajarkan), kurikulum pengajaran yang digunakan, sarana dan prasarana perangkat pembelajaran Diklat, pedoman penyelenggaraan Diklatpim Tingkat IV, kelayakan instansi penyelenggara dalam melaksanakan program Diklatpim Tingkat IV, dan alokasi anggaran dalam pelaksanaan Diklatpim Tingkat IV pemerintah Kabupaten Lahat; (c) Evaluasi Proses (Process Evaluation) yang meliputi : sistematika penyajian dari Widyaiswara, kemampuan menyajikan, penggunaan metode, penggunaan alat dan media Diklat serta performansi Widyaiswara, dan presensi daripada para peserta terkait dengan penerimaan bahan ajar yang diberikan; (d) Evaluasi Produk (Product Evaluation) yakni : pertama, aspek akademis (meliputi: pemahaman materi, kemampuan menganalisis dan pemecahan masalah, komunikasi tertulis dan komunikasi lisan) dengan indikator nilai kelulusan dari hasil ujian yang diikuti peserta, dan aspek sikap ( terdiri dari: prakarsa, disiplin, kerjasama, kepemimpinan) dengan indikator dapat dilihat dari penilaian yang diberikan dari para penyelenggara Diklatpim tingkat IV pemerintah Lahat.

\section{METODE PENELITIAN}

Didasari dengan Penggunaan model evaluasi CIPP (context, input, process and product) didalam penelitian ini, metode penilitian kualitatif dengan pendekatan studi kasus dipilih oleh peneliti untuk menemukan fakta-fakta dan mengungkapkan gambaran secara mendalam mengenai pelaksanaan program Diklatpim tingkat IV tahun 2016 di pemerintah Kabupaten Lahat. 
Teknik pengumpulan data yang digunakan dalam penilitian ini adalah wawancara dan studi dokumentasi untuk memenuhi kriteria data yang dinginkan sebagai informasi dalam penelitian.

Penyusunan pertanyaan wawancara (interview guide) dilakukan peneliti sebelum melakukan wawancara dengan menyiapkan beberapa pertanyaan berdasarkan kebutuhan data dan informasi dari model evaluasi CIPP pada program Diklatpim tingkat IV Tahun 2016 di pemerintah Kabupaten Lahat. Adapun informan pada penelitian ini terdiri dari 15 orang berdasarkan kemampuan/kapabilitas yang dapat memberikan informasi yang valid terkait dengan permasalahan yang diangkat dalam penelitian ini.

Teknik dokumentasi ini dilakukan untuk melihat sejauh mana kredibilitas dan cross check terhadap hasil wawancara yang dilakukan peneliti. Dokumen yang dimaksud dalam pelaksanaan Diklatpim tingkat IV pemerintah Kabupaten Lahat Tahun 2016 adalah erangkaian regulasi yang mengatur Diklatpim IV Kabupaten Lahat.

Tujuan adanya analisis data ini, untuk mengklasifikasi data dan informasi yang didapat agar diketahui makna dan kegunaanya dalam pemecahan masalah pada penelitian. Dalam penelitian ini, langkah-langkah yang ditempuh peneliti dalam melakukan teknik analisis data adalah: (1) Pengumpulan data: Data yang dikumpulkan oleh peneliti bersifat general dan bersifat data mentah yang belum terlihat bagian informasi penting yang dapat dan akan digunakan dalam penelitian. Setelah data ini didapatkan oleh peneliti, berikutnya peneliti melakukan teknik triangulasi untuk menguji keabsahan data yang didapat selama penelitian; (2) Reduksi Data: Reduksi data dilakukan untuk mensortir data yang tidak diperlukan dengan cara sedemikian rupa dan mendapatkan kesimpulan akhir yang dapat diverifikasi. Langkah reduksi data sangat diperlukan dalam penelitian evaluasi model CIPP yang digunakan peneliti, model evaluasi CIPP ini mengatur secara sistematis apa saja kebutuhaan data yang diperlukan dan berfungsi menjadi informasi penting di setiap aspek model evaluasi CIPP. Adapun reduksi data awal dalam penelitian ini dengan cara mengklasifikasikan data mana yang sesuai dengan bagian-bagian model evaluasi CIPP. 
Selanjutnya adalah (3) Penyajian Data: Dalam penelitian ini, data yang dibutuhkan untuk menjabarkan dan memberikan makna yang mendalam dari model evaluasi CIPP (context, Input, Process, dan product) bersifat naratif, uraian singkat, bagan, tabel, grafik dan ataupun lainnya; dan (4) Penarikan Kesimpulan: Kesimpulan dalam penelitian evaluasi Diklatpim tingkat IV tahun 2016 di pemerintah Kabupaten Lahat disusun berdasarkan setiap data dan informasi valid yang didapatkan oleh peneliti dan telah di analisis peneliti, kemudian dilihat keterkaitan satu sama lain dan dihubungkan dengan teori- teori yang melandasinya. Tahapan analisis data tersebut diharapkan menghasilkan kesimpulan yang kredibel dan dapat menjawab rumusan masalah penelitian yang ada.

Uji keabsahan data pada penelitian ini menggunakan triangulasi sumber dan triangulasi teknik. Adapun Triangulasi Sumber dilakukan dengan melakukan croschek kebenaran data yang diperoleh dari beberapa sumber, sehingga pada akhirnya akan menghasilkan suatu kesimpulan melalui kesamaan dari sumber-sumber tersebut. Dalam penelitian ini, tirangulasi teknik dilakukan dengan cara membandingkan stiap hasil wawancara yang didapatkan peneliti dan studi dokumentasi pelaksaan Diklatpim tingkat IV tahun 2016 di pemerintah Kabupaten Lahat yang ada pada lokasi penelitian.

\section{HASIL DAN PEMBAHASAN}

\section{Evaluasi Diklatpim Tingkat IV di Pemerintah Kabupaten Lahat}

Dengan pentingnya tujuan dan sasaran dari Pelaksanaan Diklatpim tingkat IV seharusnya Diklatpim tingkat IV diperuntukan bagi aparatur sipil negara yang memiliki potensi untuk dikembangan dan potensi tersebut dibuktikan dengan dokumen teknis sesuai dengan bidang jabatan struktural yang akan/telah diduduki. Belum tersedianya database kebutuhan Diklat bagi setiap individu ASN Kabupaten Lahat mengakibatkan pemanggilan calon peserta kegiatan Diklatpim Tingkat IV tahun 2016 tidak obyektif. Hal tersebut dikarenakan penetapan peserta hanya melalui surat rekomendasi pimpinan setiap satuan kerja perangkat daerah atau biasa disingkat SKPD. Hal ini diperkuat dengan data yang akan peneliti analisis pada pembahasan 
evaluasi input. Penetapan peserta Diklat baik yang sudah ataupun belum menjabat pada jabatan struktural eselon IV seharusnya diberikan analisis yang mendalam pada kompetensi yang diembannya, tidak hanya menerima rekapitulasi daftar peserta yang diajukan dari SKPD pengusul.

Perka LAN RI Nomor 20 Tahun 2015 mengatur bahwa penyelenggaran Diklatpim tingkat IV harus dilaksanakan pada lembaga Diklat pemerintah yang terakreditasi. Sedangkan hasil studi dokumentasi yang dilakukan peneliti, BKPSDM Kabupaten Lahat belum mendapatkan predikat tersebut. Berkaitan dengan hal itu, BKPSDM Kabupaten Lahat sebagai penyelenggara memerlukan ijin prinsip sebagai dasar pelaksanaan. Ijin prinsip yang didapatkan BKPSDM Kabupaten Lahat untuk melaksanaan Diklatpim Tingkat IV secara tidak langsung menandakan bahwa BKPSDM Kabupaten Lahat dari draft dokumen dan presentasi yang dilaksanakan telah memenuhi syarat untuk melaksanakan Diklatpim tingkat IV tahun 2016 di pemerintah Kabupaten Lahat.

Dikeluarkannya ijin prinsip dari lembaga penjamin mutu diklat, seharusnya pelaksanaan Diklatpim tingkat IV di pemerintah kabupaten Lahat tahun 2016 mempunyai Standard Operasional Procedure (SOP) yang baku. Namun pada prakteknya, dilihat dari aspek evaluasi input pemerintah Kabupaten Lahat mengabaikan beberapa prosedur yang telah ditetapkan sebagai standar pelaksanaan. Dengan demikian, seharusnya lembaga pemberi ijin prinsip tidak mengeluarkan ijin prinsip terkait dengan pelaksaanaan Diklatpim tingkat IV tahun 2016 di pemerintah Kabupaten Lahat karena ketidaksesuaian persyaratan awal sebagai penyelenggara.

Dilihat dari data dan informasi yang didapatkan, peneliti menyimpulkan bahwa pada dasarnya konteks pelaksanaan program Diklatpim tingkat IV di Kabupaten Lahat dilakukan hanya untuk mengikuti kebutuhan dilapangan tanpa didasari prinsip efektivitas dan analisis mendalam terhadap sebuah program. Padahal sudah selayaknya tujuan dan sasaran dari Diklatpim tingkat IV Pemerintah Kabupaten Lahat Tahun 2016 ini tercapai maksimal tidak hanya mengikuti/ataupun mengakali syaratsyarat administrasi tertulis. Kegiatan Diklatpim tingkat IV besar harapannya dapat menghasilkan pemimpin yang mempunyai kemampuan mendiagnosa dan memecahkan masalah organisasi. Adanya kegiatan pendidikan dan 
pelatihan yang terstruktur dan sistematis dapat membuat rangsangan dan pengalaman dalam menerapkan beberapa contoh konsep dalam berbagai situasi yang dapat dipraktekan secara langsung pada organisasi tempat peserta bekerja (Saks \& Belcourt, 2006).

\section{Input Pelaksanaan Diklapim Tingkat IV Kabupaten Lahat}

Program pada suatu organisasi akan berjalan dengan baik jika didukung dengan sumber-sumber daya yang memadai. Sumber daya yang memadai menurut Bryson (2007) adalah sumber daya yang berpengaruh dalam tingkat keberhasilan organisasi mencapai tujuannya.

\section{Anggaran}

Salah satu indikator yang penting dalam melaksanakan suatu program adalah ketersediannya anggaran untuk melakukan program tersebut. Perbedaan antara pelaksanaan mandiri oleh pemerintah Kabupaten Lahat dengan pengiriman peserta kepada Bandiklat yang terakreditasi dapat diketahui dari data besaran anggaran yang diperlukan untuk penyelenggaran Diklatpim tingkat IV dibagi dengan jumlah peserta yang mengikuti Diklat. Hal tersebut diakibatkan adanya perbedaan pengeluaran dan penggunaan anggaran terhadap aspek-aspek yang menjadi standar dalam pelaksanaan Diklatpim tingkat IV. Adapun perbedaan anggaran secara umum antara pelaksanaan mandiri dan pengiriman Diklatpim tingkat IV adalah tercantum dalam Tabel 1.

Penyelenggaraan mandiri di BKPSDM Kabupaten Lahat dengan pola baru terjadi kenaikan jumlah anggaran perorangan menjadi Rp 32.535.425,00 per orang pada tahun 2015 dan $\mathrm{Rp} 33.899 .194,00$ per orang pada tahun 2016. Sedangkan jika dilaksanakan dengan pola pengiriman ke lembaga Diklat lain, maka besaran dana yang dibutuhkan adalah sebesar Rp 28.053.000,00 per orang karena ditambah dengan uang intensif sebesar $\mathrm{Rp}$ 6.900.000,00 sebagaimana yang diatur pada Perda Kabupaten Lahat terkai dengan perjalanan dinas untuk diklat. Jika melihat perbandingan yang signifikan terkait dengan kebutuhan akan Diklatpim IV dan besarnya anggaran Diklatpim tingkat IV di pemerintah Kabupaten Lahat, seharusnya 
BKPSDM Kabupaten Lahat lebih memilih melakukan pengiriman dari pada melaksanakan Diklatpim tingkat IV secara mandiri.

Jika dilihat Anggaran yang paling besar ada pada Kode Rekening Belanja Perjalanan Dinas yang dianggarkan sebesar Rp 646.666.000,00 atau hampir 48\% dari seluruh total anggaran. Berdasarkan rekening tersebut, nominal yang paling besar dilihat pada tabel Perjalanan Dinas adalah untuk Kegiatan benchmarking sebesar Rp 539.750.000,00 (83 \% Anggaran Perjalanan Dinas). Namun bila tidak ada kegiatan Benchmarking to Best Practice, anggaran pelaksanaan Diklatpim tingkat IV dapat dipangkas sebesar 48\% menjadi Rp 816.217.750,00. Selain itu, bila kita bagi dengan jumlah 40 peserta yang mengikuti Diklatpim tingkat IV, maka didapatkan kebutuhan anggaran Diklat per orang hanya Rp 20.405.443,75,00. Tentu hal ini dapat mengurangi beban anggaran yang dibutuhkan dan menjadikan pelaksanaan Diklatpim. Tingkat IV tahun 2016 di pemerintah Kabupaten Lahat lebih relevan daripada pengiriman. Namun, menghilangkan benchmarking dalam penghematan anggaran tidak akan bisa dilakukan, karena benchmarking dalam pelaksanaan Diklatpim tingkat IV adalah mata Diklat wajib yang harus dilaksanakan.

\section{Panitia Penyelenggara}

Pedoman tugas dan tanggung jawab susunan kepanitian tidak dapat terlepas dari standar penyelenggara Diklat yang tertuang pada Bab IV Perka LAN Nomor 20 tahun 2015. Peraturan tersebut menyatakan bahwa pengelola dan penyelenggara tidak hanya memiliki latar pendidikan yang mumpuni, akan tetapi penyelenggara dan pengelola harus memiliki kemampuan dalam mengelola dan menyelenggarakan Diklat yang dibuktikan dengan : (1) Sertifikat Diklat Management of Training bagi pengelola Diklat; dan (2) Sertifikat Training Officer Course bagi penyelenggara Diklat.

Dapat dikatakan bahwa sumber daya aparatur yang menyelenggarakan kegiatan Diklatpim tingkat IV Tahun 2016 di Kabupaten Lahat jika ditinjau dari kepemilikan sertifikasi pengelola Diklat masih belum memadai. Berdasarkan data dan informasi lapangan, peneliti menyimpulkan bahwa kemampuan penyelenggara hanya bersifat incremental yang didasari pengalaman yang lalu, bukan berdasarkan kemampuan dan standar yang 
ditentukan. Hal ini mengakibatkan kemauan dan dukungan para panitia pelaksana dalam menjalankan tugas penyelengaraan Diklatpim tingkat IV sangat dipengaruhi oleh pengarahan yang diberikan oleh ketua panitia yang juga berperan sebagai atasan panitia dikantor.

Tabel 5.12 Checklist Ketersedian Sarana Dan Prasana

\begin{tabular}{|c|c|c|c|c|}
\hline NO & $\begin{array}{c}\text { ASPEK } \\
\text { PRASARANA }\end{array}$ & KETERANGAN & ASPEK SARANA & KETERANGAN \\
\hline 1 & Aula & Ada & $\begin{array}{l}\text { Meja dan kursi } \\
\text { belajar }\end{array}$ & Ada \\
\hline 2 & Ruang Kelas & Ada & Papan tulis & Ada \\
\hline 3 & $\begin{array}{l}\text { Ruang } \\
\text { diskusi/Seminar }\end{array}$ & Ada (kurang) & Flip Chart & Ada \\
\hline 4 & Ruang Sekretariat & Ada & Sound System & Ada \\
\hline 5 & Ruang Kebugaran & Tidak ada & $\begin{array}{l}\text { TV dan Vidio } \\
\text { Player }\end{array}$ & Tidak ada \\
\hline 6 & Ruang Komputer & Tidak ada & $\begin{array}{l}\text { Kaset/Compact } \\
\text { Disk }\end{array}$ & Ada \\
\hline 7 & Asrama & Sewa & Perekam & Ada \\
\hline 8 & $\begin{array}{l}\text { Wisma/Asrama } \\
\text { Tenaga Kediklatan }\end{array}$ & Sewa & Komputer/Laptop & Ada \\
\hline 9 & Perpustakaan & Tidak ada & LCD Projektor & Ada \\
\hline 10 & Ruang Makan & Tidak ada & Jaringan Wifi & Tidak ada \\
\hline 11 & Fasilitas Olahraga & Tidak ada & Buku Referensi & Tidak ada \\
\hline 12 & Fasilitas Hiburan & Tidak ada & $\begin{array}{l}\text { Modul/Bahan } \\
\text { ajar }\end{array}$ & Tidak ada \\
\hline 13 & $\begin{array}{l}\text { Unit } \\
\text { Kesehatan/Poliklinik }\end{array}$ & Tidak ada & $\begin{array}{l}\text { Tehnologi } \\
\text { Multimedia }\end{array}$ & Tidak ada \\
\hline 14 & Tempat Ibadah & Tidak ada & Tidak ada & Tidak ada \\
\hline
\end{tabular}

Sumber : Data diolah

Peneliti 


\section{Karakteristik Peserta}

Menurut Nitisemito (1986) salah satu hal yang harus dipertimbangkan dalam pencapaian keberhasilan pendidikan dan pelatihan diantaranya yakni pemilihan calon peserta. Untuk menganalisa kesesuain peserta dengan persyaratan yang ada, perlu diketahui tentang penjabaran daripada syarat yang diatur didalam Perkalan Nomor 20 Tahun 2015 tersebut. Alur penetapan peserta pada prosesnya tidak membutuhkan waktu yang lama, karena penetapan

Peserta yang telah disetujui oleh Sekretaris Daerah langsung berhak untuk mengikuti Diklatpim tingkat IV. Padahal, analisa kebutuhan adalah alat untuk mengidentifikasi masalah guna menentukan tindakan yang tepat (Morrison,2001:27). Tindakan yang tepat disini berarti penentuan peserta yang memang memenuhi persyaratan, kompeten, dan berdampak baik terhadap organisasi yang dipimpinnya.

Dari fakta yang ada, ditemukan fakta proporsi peserta yang ditetapkan menjadi peserta Diklatpim tingkat IV tahun 2016 di pemerintah Kabupaten Lahat 55 persen berlatar belakang pendidikan ekonomi. Dengan tidak adanya alasan yang kuat dan dokumen analisis dalam menetapkan proporsi penetapan peserta, maka dapat disimpulkan penetapan para peserta tidak melalui kajian yang mendalam. Sehingga menimbulkan persepsi negatif di lingkungan pejabat struktural eselon IV Kabupaten Lahat terutama yang belum mengikuti Diklatpim tingkat IV.

Dari hasil telaah dokumen dan wawancara langsung dengan panitia, diketahui bahwa tidak ada peserta yang melampirkan sertifikat TOEFL ketika panitia memeriksa kelengkapan dan menginventarisasi usulan peserta Diklatpim tingkat IV tahun 2016. Seharusnya pengumpulan sertifkat TOEFL dapat dijadikan poin seleksi terhadap peserta yang ingin mengikuti Diklatpim tingkat IV sebagai syarat bahwa peserta memiliki pengetahuan yang cukup untuk mengikuti Diklatpim tingkat IV. Akan tetapi panitia tidak membuat hal tersebut menjadi poin seleksi melainkan memfasilitasi para peserta untuk melaksanakan test toefl ketika penetapan peserta telah dilaksanakan. Selain itu, pemilihan lembaga yang melaksanakan TOEFL bagi peserta juga bukan 
lembaga yang disyaratkan pada poin 4 BAB III Perka LAN RI Nomor 20 Tahun 2015.

Terkait dengan uraian diatas, peneliti mengambil kesimpulan bahwasanya mekanisme pencalonan dan penetapan peserta Diklatpim tingkat IV tidak sesuai dengan peraturan yang telah ditetapkan. Dengan banyaknya poin administrasi yang di langgar oleh panitia, mengakibatkan adanya kesan penetapan peserta Diklatpim tingkat IV Kabupaten Lahat tahun 2016 sarat dengan kepentingan tertentu. Berdasarkan tujuan dan sasaran Diklatpim tingkat IV, dibutuhkan pengalaman widyaiswara dalam mengkonstruksikan objek belajar. Hal tersebut agar peserta didik dapat mengkonstruksikan struktur mental yang terdiri dari dari pengetahuan dan konsep yang tersimpan di dalam memori sehingga dapat ditransfer pada lingkungan organisasi peserta. Sebagaimana yang telah dijelaskan pada pembelajaran konstruktivistik sebagai experience based learning (Ertmer dan Newby, 2013).

\section{Karakteristik Tenaga Kediklatan}

Penetapan widyaiswara yang ditentukan oleh Bandiklat Provinsi selaku penjamin mutu pendidikan, dan Narasumber dari Daerah telah sesuai dengan persyaratan yang diatur didalam Perka Lan RI Nomor 20 tahun 2015 yang merupakan pedoman pelaksanaan Diklatpim tingkat IV tahun 2016 di pemerintah Kabupaten Lahat. Sedangkan untuk performa yang tidak memuaskan kebanyakan berasal dari narasumber lokal (narasumber dari lingkup pemerintah Kabupaten Lahat). Adapun performa yang tidak memuaskan menurut peserta adalah mengenai cara penyampaian materi yang diberikan.

\section{Sarana dan Prasarana}

Ketersediaan sarana dan prasarana merupakan bagian yang tidak dapat dipisahkan dari proses Diklat. Adapun kelengkapan sarana dan prasarana BKPSDM sebagai penyelenggra Dilat Kepemimpinan Tingkat IV di Kabupaten Lahat dapat dilihat dari Tabel 2. 
Berdasarkan fakta dan informasi yang peneliti temui di lapangan, fasilitas yang dimiliki BKPSDM Kabupaten Lahat tidak memadai. Fasilitas tersebut berupa ruang kelas yang digunakan untuk mendukung proses pembelajaran maupun fasilitas penunjang lainnya seperti asrama dan sarana olahraga. Namun berkaitan dengan keluarnya ijin prinsip pelaksanaan, panitia penyelenggara diharuskan mencari solusi agar penyelenggaraan Diklatpim tingkat IV Tahun 2016 terlaksana dengan baik.

Dari berbagai input yang telah dijelaskan diatas bila dikaitkan dengan teori CIPP yang dikemukakan Stufflebeam (2007) diketahui bahwa aspek input merupakan bagian yang utama dari keberhasilan atau kegagalan atas usaha yang dirancang. Dalam catatan evaluasi yang dilakukan peneliti, BKPSDM Kabupaten Lahat terlalu banyak mengabaikan aspek-aspek administrasi. Menurut (David, 2002), pentingnya input dalam suatu program membutuhkan pertangggungjawaban yang diemban oleh para pelaksana kegiatan. Baik itu peserta, widyaiswara, tenaga kediklatan lainnya, mentor, coach, dan penyelenggara sebagai pemenuhan akuntabilitas untuk mencapai sasaran yang ingin dicapai.

\section{Proses pelaksanaan Diklatpim tingkat IV Kabupaten Lahat}

Jika hanya dilihat dari proses penyelenggaraan yang merupakan bagian dari evaluasi model CIPP, peneliti berpendapat BKPSDM kabupaten Lahat sebenarnya sudah berusaha maksimal untuk sesuai dengan agenda dan perencanaan yang telah ditetapkan dalam menyelenggarakan Diklatpim tingkat IV tahun 2016 di pemerintah Kabupaten Lahat. Akan tetapi, ketidaksesuaian adminitrasi serta kurangnya sarana dan prasarana mengganggu kelancaran dan tujuan dari pelaksanaan.

Adapun apresiasi yang dapat diberikan dalam hal ini adalah bagaimana panitia dan pihak penyelenggara tetap memfasilitasi dan mengakomodir semua proses ditengah kurangnya sumber daya pendudukung dan administrasi. Proses tersebut diantaranya yang berkenaan dengan hubungan dan harmonisasi antara widyaiswara, coach, mentor, dan peserta dalam menghasilkan proyek perubahan sebagai tujuan akhir pelaksanaan Diklatpim tingkat IV tahun 2016 di pemerintah Kabupaten Lahat. 


\section{Product pelaksanaan Diklatpim IV Kabupaten Lahat}

Fokus kajian selanjutnya pada dimensi ini erat kaitannya dengan product program Diklat itu sendiri, yakni menerangkan bagaimana keberhasilan penyelenggaraan Diklatpim tingkat IV dilakukan dan hasil capaian peserta. Hal yang dievaluasi dari peserta dalam pelaksanaan Diklatpim tingkat IV yaitu terkait pengetahuan dan pengalaman dalam memimpin implementasi proyek perubahan. Kegiatan berbagi pengetahuan dilaksanakan dalam bentuk seminar implementasi proyek perubahan. Hanya peserta yang berhasil mengimplementasikan proyek perubahan yang dinyatakan telah memiliki kompetensi operasional dan dinyatakan lulus. Berdasarkan Perka LAN Nomor 20 Tahun 2015, penilaian kelulusan peserta pengembangan kompetensi kepemimpinan pengawas difokuskan pada aspek proyek perubahan. Komponen penilaian proyek perubahan terdiri atas perencanaan inovasi sebesar $40 \%$ dan manajemen perubahan sebesar $60 \%$.

Penetapan hasil kelulusan peserta Diklat termuat dalam berita acara rapat evaluasi dan kelulusan bagi peserta Diklat kepemimpinan tingkat IV angkatan I Kabupaten Lahat Provinsi Sumatera Selatan Tahun 2016 dengan nomor 890/1040/BA/Bandiklat/2016. Sebanyak 40 orang dinyatakan lulus pada tanggal 14 Juni 2016 di Bandiklat dengan rincian 36 orang dinyatakan lulus dan berhak mendapatkan surat Tanda Tamat Pendidikan dan Pelatihan (STTPP) Diklatpim tingkat IV Tahun 2016. Sedangkan 4 orang dinyatakan lulus ditunda dengan kewajiban melakukan perbaikan pada laporan proyek perubahan.

Penyelenggaraan Diklatpim tingkat IV tahun 2016 ini telah mampu merubah mindset para peserta kearah yang lebih baik sesuai dengan tujuan dan sasaran yang ingin dicapai. Meskipun penilaian itu bersifat sementara tetapi sangat relevan dengan kurikulum Diklatpim pola baru yang lebih mampu menjadikan peserta agent of change. Dengan demikian diharapkan berguna bagi organisasi dalam rangka menciptakan citra ASN yang berguna bagi masyarakat. Oleh karena itu, evaluasi keseluruhan diperlukan terhadap program yang dilaksanakan agar terlihat apakah program yang dilakukan sesuai dengan aturan-aturan yang telah ditentukan dan apakah telah 
mencapai tujuannya. Akan tetapi, perlu diketahui pula bahwa fakta yang ditemukan peneliti menunjukkan BKPSDM Kabupaten Lahat tidak membuat sebuah evaluasi menyeluruh terhadap pelaksanaan Diklatpim tingkat IV yang dilaksanakan.

\section{Hambatan Pelaksanaan Diklatpim Tingkat IV Kabupaten Lahat}

Bagian ini mendiskusikan mengenai hambatan pelaksanaan dan hambatan yang akan mendatang. Penulis, terlebih dahulu akan menjelaskan mengenai hambatan pelaksanaan Diklatpim IV Kabupaten Lahat.

\section{Peserta}

Penentuan peserta merupakan hambatan awal yang dihadapi dalam pelaksanaan Diklatpim tingkat IV tahun 2016 di Kabupaten Lahat. Hal tersebut dikarenakan tidak adanya proses seleksi yang dilaksanakan oleh BKPSDM. Proses seleksi ini lah yang seharusnya menjadi cikal bakal sebagai pre-test terhadap calon peserta Diklatpim tingkat IV. Pre-test tersebut sangat berguna untuk melihat bagaimana perubahan yang didapat peserta setelah mengikuti Diklat, disamping untuk menepis lahirnya persepsi pemilihan peserta yang subjektif dilingkungan ASN Pemerintah Kabupaten Lahat.

\section{Sertfikat Toefl}

Keharusan calon peserta untuk memiliki kemampuan bahasa Inggris yang dibuktikan dengan sertifikat TOEFL seharusnya menjadi standar dalam menentukan peserta. Pihak BKPSDM Kabupaten Lahat sudah mempersiapkan hal ini jauh-jauh hari dengan menginfokan kepada setiap pejabat struktural eselon IV yang belum mengikuti Diklatpim tingkat IV. Namun, pada pelaksanaannya masih banyak peserta yang tidak memiliki sertifikat TOEFL. Untuk mensiasati hal tersebut, panitia memfasilitasi para peserta dengan melakukan test TOEFL bekerjasama dengan salah satu lembaga bahasa yang ada di Kabupaten Lahat. Akan tetapi, lembaga tersebut bukan lah lembaga yang sesuai dengan standar di dalam Perka LAN Nomor 20 Tahun 2015 dan panitia tetap menggunakan lembaga tersebut untuk 
membantu peserta dalam memenuhi salah satu persyaratan peserta Diklatpim IV. Padahal waktu pelaksanaan tes sertifikasi bahasa juga telah menggangu agenda Diklatpim tingkat IV yang telah disusun sebelumnya. Perlu diketahui bahwa memfasilitasi peserta untuk mendapatkan Sertifikat TOEFL telah menyalahi tugas pokok dan fungsi dari panitia Diklatpim tingkat IV. Apalagi sertifikat TOEFL merupakan persyaratan wajib yang harus dilampirkan peserta sebelum mengikuti Diklat.

\section{Sarana dan Prasarana}

Berdasarkan fakta yang ada, fasilitas yang dimiliki BKPSDM Kabupaten Lahat tidak memadai untuk mendukung proses pembelajaran. Hal tersebut terlihat pada table 5.13 yang menunjukkan bahwa hanya terdapat 12 item dari 27 item yang memenuhi persyaratan sebagai standar sarana dan prasarana pelaksanaan Diklatpim tingkat IV. Item yang memenuhi persyaratan tersebut pun diperoleh dengan sistem sewa dan pinjam oleh BKPSDM Kabupaten Lahat. Hal ini mengakibatkan munculnya masalah lain, yaitu terkait jarak dan peningkatan anggaran pelaksanaan Diklatpim tingkat IV Tahun 206 di Pemerintah Kabupaten Lahat. Selain itu, hambatan mengenai sarana pembelajaran juga dikarenakan tidak adanya modul, jaringan internet, dan perpustakaan sebagai tempat mencari referensi.

Selanjutnya, penulis akan menyajikans erangkaian daftar hambatan yang mungkin akan terjadi dimasa depan. Ini dimaksdukan untuk memberikan gambaran kepada oihak terkait untuk mengantisipasi hambatan- hambatan dalam penyelenggaraan Diklatpim IV Kabupaten Lahat.

\section{Ketersedian Anggaran}

Ketersediaan anggaran perlu mendapat perhatian karena biaya penyelenggara Diklat PIM pola baru sesuai dengan peraturan terbaru Perka LAN RI nomor 20 Tahun 2015 mengalami peningkatan hampir dua kali lipat dibanding pola lama. Dilihat dari banyaknya jumlah pejabat yang belum mengikuti Diklapim Tingkat IV yakni sebanyak 454 Orang dan besarnya jumlah anggaran yang dibutuhkan terhadap biaya penyelenggaraan Diklatpim tingkat IV tentu dimasa yang akan datang akan menguras ketersediaan 
anggaran pada Pemerintah Kabupaten Lahat, meskipun upaya yang dilakukan oleh BKPSDM Kabupaten Lahat dilaksanakan secara bertahap pertahun anggaran. Peningkatan biaya yang cukup signifikan ini terutama disebabkan adanya dua kali off campus. Sehingga dalam proses pembelajaran kenaikan anggaran yang cukup besar terjadi pada implementasi on-off campus, yaitu ketika peserta harus melakukan perjalanan pergi-pulang dari tempat asal ke lokasi Diklat sebanyak tiga kali perjalanan bolak-balik, sementara dalam pola lama perjalanan ini cukup dilakukan satu kali bolakbalik.

\section{Pemberdayaan Alumni Diklatpim Tingkat IV}

Tidak adanya pemberdayaan alumni Diklatpim tingkat IV dalam fase evaluasi jangka panjang, menjadikan beban bagi pembiayaan pelaksanaan Diklatpim tingkat IV. Hal tersebut dikarenakan keberhasilan proyek perubahan yang dibawa peserta tidak dapat diaplikasikan di sektor lain maupun tidak berhubungan dengan adanya reward yang diberikan oleh BKPSDM kepada para Alumni Diklatpim tingkat IV. Untuk melihat hasil yang didapat dan memberikan reward terhadap alumni Diklatpim tingkat IV diperlukannya analisis dan evaluasi yang panjang dari beberapa stakeholder Pembina kepegawaian. Hal ini yang dapat menjadi hambatan dalam melakukan pemberdayaan bagi alumni Diklatpim tingkat IV.

\section{KESIMPULAN}

Berdasarkan hasil penelitian yang telah dilakukan terhadap penyelenggaran Diklatpim tingkat IV Tahun 2016 di Kabupaten Lahat, dilihat dari aspek proses dan product telah sesuai dengan agenda yang ditentukan dan dianggap berhasil. Namun, jika dilihat dari aspek konteks dan input terdapat beberapa hal yang tidak sesuai dengan maksud dan tujuan dari adanya program Diklatpim tingkat IV di pemerintah Kabupaten Lahat.

Keberhasilan penyelenggaran Diklatpim tingkat IV tahun 2016 di Kabupaten Lahat hanya dilihat sebagai sebuah kegiatan yang bersifat sementara tanpa mendalami maksud dan tujuan dari program Diklatpim tingkat IV. Hal ini terlihat dari tidak adanya seleksi yang ketat terhadap peserta, belum tertibnya administrasi, serta sarana dan prasarana yang tidak layak dalam pelaksanaan Diklatpim tingkat IV tahun 2016 di Kabupaten Lahat. 
Dilihat dari aspek anggaran, seharusnya pelaksanaan Diklatpim tingkat IV tahun 2016 di Pemerintah Kabupaten Lahat lebih efektif dan efesien dari melaksanakan pengiriman peserta diklat pada instansi lain, jika aspek sarana dan prasarana yang dimiliki pemerintah Kabupaten Lahat memadai. Dan juga melakukan penghematan pada penunjukan lokasi tujuan benchmarking.

Dalam pelaksanaan Diklatpim tingkat IV seharusnya terdapat evaluasi pasca Diklat yang dilakukan untuk memantau kinerja alumni Diklatpim tingkat IV tahun 2016 di pemerintah Kabupaten Lahat. Akan tetapi, monitor dan evaluasi tersebut tidak dilakukan sehingga menimbulkan persepsi pelaksanaan

Diklatpim tingkat IV tersebut hanya sebagai kegiatan biasa yang tidak berkesinambungan.

\section{DAFTAR PUSTAKA}

\section{A.BUKU}

Abdussamad, Y. (2017). Pengembangan Sumber Daya Manusia Aparatur Melalui Kompetensi. Jurnal Ekonomi dan Bisnis Universitas Negeri Gorontalo, vol 6

Agustino, Leo. (2014). Dasar-Dasar Kebijakan Publik. Bandung: Alfabeta.

Alwi, S. (2008). Manajemen Sumber Daya Manusia strategi keunggulan kompetitif. yogyakarta: BPFE-YOGYAKARTA.

Amaluis, D. (2014) Analisis efektifitas program pelatihan diklat PIM III terhadap kompetensi pejabat eselon III di Pemerintah Kabupaten Agam. Journal of Economic and Economic Education 3(1): 18-26.

Arikunto, S. (2009) Evaluasi Program Pendidikan, Jakarta:PT Bina Aksara. Arikunto, S., \& Jabar, C.S.A. (2008). Evaluasi program pendidikan. Jakarta: Bumi Aksara.

Arikunto, Suharsimi. 2010. Prosedur Penelitian. Jakarta: Rineka Cipta.

Armstrong, Gery. 2010. Prinsip-prinsip Manajemen Sumber Daya Manusia. Erlangga. Jakarta

Berman, E. M., Bowman, J. S., West, J. P., \& Wart, M. R. Van. (2013). Human Resource Management in Public Service (Fourth). Los Angeles: Sage Publication, 1td.

Blanchard, P.Nick \& Thacker, James W. (2004). Effective Training: Systems, Strategies, and Practices (2nd ed). New Jersey: Pearson Education.

Bryson, Jhon M. 2007. Perencanaan Strategis Bagi Organisasi Sosial. Cet 8. Yogyakarta: Pustaka Pelajar

Bungin, Burhan. 2009. Penelitian Kualitatif. Jakarta: Kencana.

Covey, Stephen R., dkk.. 2015. First Things First, The Interactive Edition. Miami : Franklin

Crawford, John., 2000, Evaluation of Libraries and Information Services, the association for information management and information management international, Edisi 2, Aslib, London.

Creswell, John W. 2009. Research Design: Qualitative, Quantitative, and Mixed Method Approaches. New york : sage Publications. 
Darmawan, Didit. 2013. Prinsip-prinsip Perilaku Organisasi. Pena Semesta.

David, F. R. (2002). Concept of Strategic Management (Seventh; A. Widyantoro, ed.). Jakarta: Pearson Education Asia Pte. Ltd. dan PT Prenhallindo.

Dessler, G. (2015). Manajemen Sumber Daya Manusia. Jakarta: PT. Indeks.

Drejer, A. (2001). Illustrating competence development. Measuring Business Excellence, 5(3), 6-10. https://doi.org/10.1108/13683040110397293

Dunn, William N. 2003. Muhadjir Darwin (Penyunting). Pengantar Analisis Kebijakan Publik. Yogyakarta: Gadjah Mada University Press.

Dwiyanto, Agus. 2013. Reformasi birokrasi public di Indonesia. PSKK UGM. Yogyakarta. Edison Emron, dkk, 2016, Manajemen Sumber Daya Manusia, Strategi dan perubahan Dalam Rangka Meningkatkan Kinerja Pegawai dan Organisasi, cetakan pertama, Penerbit: Alfabeta, Bandung

Effendi, S. (2010). Reformasi Tata Pemerintahan: Menyiapkan Aparatur Negara untuk mendukung Demokratisasi politik dan ekonomi terbuka. Yogyakarta: Gadjah Mada University Press.

\section{B. Lain-lain (Dokumen, Jurnal, dan Majalah)}

Creswell, J. 2015. Penelitian Kualitatif dan Desain Riset: Memilih di Antara Lima Pendekatan (Vol. 3). Yogyakarta: Pustaka Pelajar.

Fadilla Astra, J.M.2016. Pengaruh Pendidikan dan Pelatihan struktural terhadap Kompetensi Kepemimpinan Aparatur Sipil Negara Studi di Sekretariat Daerah Kota Bitung. Retrivied Desember 12, 2018, from http://ejournal.unsrat.ac.id/index.php/JAP/article.

Fitzpatrick, J. L., Sanders, J. R. \& Worthen, B. R. (2004) Program evaluation: Alternative approaches and practical guidelines : Allyn \& Bacon.

Grossman, R., \& Salas, E. (2011). The transfer of training: What really matters. International Journal of Training and Development, 15(2), 103120. https://doi.org/10.1111/j.1468-2419.2011.00373.

Hakan, K., \& Seval, F. (2011). CIPP evaluation model scale : development , reliability and validity. Procedia - Social and Behavioral Sciences, 15, 592-599. https://doi.org/10.1016/j.sbspro.2011.03.146

Hariandja, Marihot T.E, 2012. Manajemen Sumber Daya Manusia. P.T Grasindo. Jakarta

Hasibuan, Malayu S.P,2014. Manajemen Sumber Daya Manusia, edisi revisi. Cetakan ke delapan belas, Penerbit : Bumi Aksara, Jakarta.

Hendrayanto, Kamdin Masruhi. 2018. Penguatan Kompetensi, Lingkungan Kerja dan Pendidikan Dalam Meningkatkan Kinerja Karyawan BPJS ketenagakerjaan Cabang Gorontalo. Jurnal Manajemen Bisnis Vol.5 No. 2 September 2018.

Herlambang Rosianton, dkk. 2014. Implementasi Pengembangan Kompetensi Sumber Daya Manusia Dalam Meningkatkan Kinerja Pegawai Di Kantor Camat Bontang Barat Kota Bontang. ejurnal administrative reform, volume 2, Nomor 1 .

Hughes, R. L., Giinnet, R. C., \& Curphy, G. J. (2012). Leadership: Enchancing the Lessons of experience (Seventh). New York: McGrawHills.

Ishii, R., Rohitarachoon, P., \& Hossain, F. (2013). HRM Reform in Decentralised Local Government: Empirical Perspectives on 
Recruitment and Selection in the Philippines and Thailand. Asian Journal of Political Science, 21(3), 249-267. https://doi.org/10.1080/02185377.2013.864514

Kadarisman. 2012. Natural Intelligence Leadership: Cara Pandang Baru Terhadap Kecerdasan dan Karakter Kepemimpinan. Jakarta: Raih Asa Sukses

Kadarisman. 2013. Manajemen Pengembangan Sumber Daya Manusia. Jakarta : Rajawali Pers.

Kelly, M., \& Messina., S. (2011). Training Needs Analysis (TNA). He Royal Australian and New Zealand College of Radiologists, 1.

Kim, P. S. (2002). Civil service reform in Japan and Korea: Toward competitiveness and competency. International Review of Administrative Sciences, 68(3), 389-403. https://doi.org/10.1177/0020852302683006

Kirkpatrick, D. L. (1998) Evaluating Training Programs - The four levels, San Francisco:Berrett-Koehler.

Kotter, J. P. (1990). Good Management ontrols complexity: effective leadership produces useful change. Harvard Business Review, 40(4), 292-. Retrieved from http://scholar.google.com/scholar?hl=en\&btnG=Search\&q=intitle:Copy right+(C2001.+All+Rights+Reserved.\#0\%5Cnhttp://scholar.google.com/ scholar?hl=en\&bt=Search\&q=intitle:Copyright $\mathbb{C}+2001+$ All+Rights + Reser ved\#0

Lah,T. J., \& Perry, J. L. (2008). The Diffusion of the Civil Service Reform Act of 1978 in OECD Countries: A Tale of Two Paths to Reform. Review of Public Personnel Administration, 28(3), 282299.https:/ / doi.org/10.1177/0734371X08319950

Macke, J., \& Genari, D. (2019). Systematic literature review on sustainable human resource management. Journal of Cleaner Production, 208, 806815. https://doi.org/10.1016/j.jclepro.2018.10.091

Mangkunegara, Anwar Prabu. 2011. Manajemen Sumber Daya Manusia Perusahaan. Bandung, PT Remaja Rosdakarya.

Miles, M. B., Huberman, A. M. dan Saldana, J. 2014. Qualitative Data nalysis: A Method Sourcebook. CA: Sage Publications.

Mirzazadeh, A., Gandomkar, R., \& Mortaz, S. (2016). Undergraduate medical education programme renewal: a longitudinal context, input, process and product evaluation study. 15-23. ttps://doi.org/10.1007/s4003715-0243-3

Moeheriono. 2010. Pengukuran Kinerja Berbasis Kompetensi. Bogor : Ghalia Indonesia. Moleong, L. 2011. Metodologi Penelitian Kualitatif Edisi Revisi. Bandung: PT Remaja Rosdakarya

Mukhopadhyay, K., Sil, J., \& Banerjea, N. R. (2011). System for Sustainable Development by Innovative Organizations: https: / / doi.org/ 10.1177/097226291101500206

Nazir, Moh. 2013. Metode Penelitian. Bogor: Ghalia Indonesia. Nitisemito, Alek S. 1996. Manajemen Personalia. Jakarta.Ghalia Indonesia

Noe, Raymond A. (2002). Employee Training and Development. Second Edition. New York: McGraw-Hill Companies.

Notoatmodjo, Soekidjo. 2010. Pengembangan Sumber Daya Manusia. Penerbit Rineka Cipta. Jakarta 
Ostroff, C. (1991) Training effectiveness measures and scoring schemes: A comparison. Personnel Psychology, 44(2):353-374.

Pallai, K., \& Gregor, A. (2016). Assessment of effectiveness of public integrity training workshops for civil servants - A case study. Teaching Public Administration, 34(3),

247-269. https:/ / doi.org/ 10.1177/0144739416650431

Rajendran, P., \& Udayasuriyan, G. (2015). Effectiveness of Training and Development in Information Technology Enabled Service Sector

Saks, A. M., \& Belcourt, M. (2006). AN INVESTIGATION OF TRAINING ACTIVITIES AND TRANSFER OF TRAINING IN ORGANIZATIONS. Human Resource Management, 45(4),629-648. https: / / doi.org/ 10.1002/hrm.20135

Sax, G. (1980). Principles of educational and psychological measurement and evaluation, (2nd ed.). California: Wandsworth Publishing Company. Scriven, Michael. 1991. Evaluation Thesaurus, 4th edition. Newbury Park, California: Sage Sage Publications, Inc.

Sharma, R. R. (2017). A Competency Model for Management Education for Sustainability. Vision, $21(2), \quad \mathrm{x}-\mathrm{xv}$. https://doi.org/10.1177/0972262917700970

Siagian, S. P. (1998) Manajemen Sumber Daya Manusia, Jakarta:Bumi Aksara.

Simamora, Hendry, 2016. Manajemen Sumber Daya Manusia. edisi ketiga, cetakan pertama. Penerbit : Sekolah Tinggi Ilmu Ekonomi YKPN. Yogyakarta

Sjafrizal, 2014. Fungsi Pembangunan Nasional. Jakarta : Rajawali Press

Sorcher, M., \& Brant, J. (2002). Are You Picking The Right Leaders. Harvard Business Review, 78-85.

Stufflebeam, Daniel L. 2003. "The CIPP model for evaluation," makalah disampaikan pada Annual Cnfrence of the Oregon Program Evaluators Network (OPEN)

Stufflebeam, D. L., \& Coryn, C. L. S. (2007). Evaluation Theory, Models, And Applications. San Fransisco: Jossey-bass

Sugiyono. 2002. Manajemen Diklat. Bandung: Alfabeta. . 2011. Metode Penelitian Kuantitatif Kualitatif Dan R \& D. Bandung. Alfabeta

2013. Memahami Penelitian Kualitatif, Alfabeta, Bandung

. 2018. Metode Penelitian Evaluasi (Pendekatan Kuantitatif, Kualitatif, dan Kombinasi (Pertama; Y. Yuniarsih, ed.). Bandung: CV. ALFABETA.

Sugiyono. (2018). Metode Penelitian Evaluasi (Pendekatan Kuantitatif, Kualitatif, dan Kombinasi (Pertama; Y. Yuniarsih, ed.). Bandung: CV. ALFABETA

Sulistiyani, Ambar Teguh. (2011). Memahami Good Governance Dalam Perspektif Sumber Daya Manusia. Yogyakarta. Penerbit Gava Media.

Sustrisno, Edy. 2011. Manajemen Sumber Daya Manusia. Jakarta : Kencana

Suwanto, 2011. Manajemen Sumber Daya Manusia dalam organisasi public dan bisnis. Alfabeta. Bandung

Thoha, M. (2012). Prilaku Organisasi : Konsep Dasar dan Aplikasinya (1st ed.). Jakarta: Rajawali Press.

Thoha, M. (2014). Manajemen Kepegawaian Sipil di Indonesia (Cetakan ke). Jakarta: PRENADAMEDIA GROUP. 
Topno, H. (2012). Evaluation of training for development. Participatory evaluation: a case study. IOSR Journal of Business and Management, $5(2), 6$.

Uys, L. R., Gwele, N. S. (2005) Curriculum Development in Nursing Process and Innovation. New York: Routledge Veithzal, Rivai. 2005. Manajemen Sumber Daya Manusia. Jakarta : Raja Grafindo Persada

Wu, J. L. (2013). The study of competencybased training and strategies in the public sector: Experience from Taiwan. Public Personnel Management, 42(2), 259-271. https://doi.org/10.1177/009102601348 7124

Yang, K., Wu, F., Xu, X., \& Chen, T. (2012). The Challenge of Civil Servant Training in China. Review of Public Personnel Administration, 32(2), 169-191. https://doi.org/10.1177/0734371x1243 8245

Yustiono, E. (2009) Reformasi Birokrasi melalui Revitalisasi Pelatihan SDM Aparatur: Suatu Tinjauan terhadap Diklat Kepemimpinan. Jurnal Ilmu Administrasi, VI(4): 321-337 